O. S. Voloshyn, M. V. Hoviak, O. V. Popadiuk

Ternopil Volodymyr Hnatiuk National Pedagogical University, Ukraine

PECULIARITIES OF THE FUNCTIONAL STATE OF THE ORGANISM AND PROCESSING OF THE SENSORY INFORMATION IN YOUNG PEOPLE

The aim of the work is to study the functional indicators of the cardiovascular and respiratory systems, indicators of the efficiency of processing of visual information and motor response in adolescents with different levels of functional reserves of the heart. We studied indicators of heart rate, blood pressure, Skibinsky index, Rosenthal's test, the speed of the visual-motor reaction (simple and differentiated), the number of errors made during the examination, the analysis of the indicators of the correction test, the volume of operational visual memory, the dynamics of the analysis of Schulte tables, the volume and distribution of attention.

The study demonstrated that the functional indicators of the cardiovascular system are within the permissible limits. However, the heart rate of individuals with a satisfactory level of heart efficiency tends to approach the upper physiological limit. Skibinsky's index corresponds to a satisfactory level for the females. This index indicates the average potential of the external respiration system and the correspondence of activity with the blood circulatory system.

For the analysis of Schulte tables, the individuals of the first group spent $161.8 \mathrm{~s} \pm 10.37 \mathrm{~s}$, which is significantly faster than the index of the second group. Studies have not shown a relationship between the level of heart performance and indicators of the distribution of attention. However, the indicators of the volume of operative visual memory in individuals of the first group are much better: $65 \%$ of individuals have a high level (the same index in the second group is $20 \%$ ), the participants with a low level of operative visual memory are absent, in contrast to the second group. The speed of simple and differentiated sensorimotor reactions in individuals of the first group is higher than those in the second group by $11.4 \%$ and $10.6 \%$, respectively. This indicates a sufficient level of plasticity of nervous processes and the efficiency of arousal development.

The performance indicators of the cardiovascular and respiratory systems, the speed of reactions of the nervous system of the examined, the efficiency of processing sensory information indicate the maturity of the functional systems of the body and are the physiological basis for the formation of an adequate functional state of the body. Individuals with a Rufier index level above the average showed less tension in the work of the heart and an effective course of sensorimotor reactions, indicating a sufficient level of plasticity of nervous processes.

Keywords: functional state of the body, heart rate, blood pressure, Skibinsky index, sensorimotor reactions.

Надійшла 30.04.2021.

УДК: 611.819-018.1-02:616-001.17]-092

doi: 10.25128/2078-2357.21.1-2.9

С. О. ЛИТВИНЮК, П. Г. ЛИХАЦЬКИЙ, І. Б. ПРИВРОЦЬКА, Н. Є. ЛІСНИЧУК

Тернопільський національний медичний університет імені І. Я. Горбачевського МОЗ України

майд. Волі, 1, Тернопіль, 46001

e-mail: lytvynyuk@tdmu.edu.ua

\title{
УЛЬТРАСТРУКТУРНІ ОСОБЛИВОСТІ НЕЙРО-ГЛІАЛЬНО- КАПІЛЯРНИХ ВІДНОСИН САЗ ПОЛЯ ГІПОКАМПА ЧЕРЕЗ 21 ДОБУ ЗА УМОВ ЕКСПЕРИМЕНТАЛЬНОЇ ТЕРМІЧНОЇ ТРАВМИ
}

Тяжка термічна травма призводить до ряду морфофункціональних змін, які виникають при порушенні цілісності або втраті шкіри при глибоких опіках, опосередковано розвиваються значні структурно-метаболічні порушення в усіх органах та системах ураженого організму. Встановлено, що через 21 добу після нанесення експериментальної термічної травми в 
нейроцитах, клітинах глії та мікроциркуляторному руслі САЗ поля гіпокампа виникали значні альтеративні зміни, які розвиваються на фоні надмірної ендогенної інтоксикації.

Ключові слова: гіпокамп, поле САЗ, нейрочити, гемокапіляри, субмікроскопічні зміни, термічна травма.

Термічна травма одна із найпоширеніших видів травм, при якій первинно ушкоджується зовнішній покрив тіла, що виконує функцію захисту $[3,7,8,10]$. Опосередковано виникають різні структурно-функціональні порушення всіх органів і систем організму, проте патогенез їх пошкоджень, динаміка змін, пристосувально-компенсаторні та деструктивні процеси до кінця ще не вивчені $[4,6,9]$. Це пов'язано із надмірним виділенням опікових токсинів, які утворюються в рані і транспортуються кров'ю по всьому організмі, у результаті розвивається ендогенна інтоксикація на фоні опікової травми шкіри.

Згідно 3 даними наукової літератури до цього часу дослідження морфофункціонального стану структурних компонентів гіпокампа - центрального органа лімбічної системи, що відповідає за забезпечення життєдіяльності організму та підтримку його гомеостазу, а також сприймає реакцію на стрес при термічній травмі, залишаються недостатньо вивченими $[2,5]$.

Тому метою роботи було вивчити субмікроскопічні зміни нейро-гліально-капілярних відносин САЗ поля гіпокампа через 21 добу після експериментальної термічної травми шкіри.

\section{Матеріал і методи досліджень}

Досліди проведено на 30 статевозрілих білих щурах-самцях. Тварин утримували в стандартних умовах віварію Тернопільського національного медичного університету імені I. Я. Горбачевського MO3 України на загальному харчовому раціоні. Догляд за тваринами та всі маніпуляції проводили із дотриманням правил «Свропейської конвенції про захисту хребетних тварин, що використовуються для дослідних та інших наукових цілей» (Страсбург, 1986), а також у відповідності до положень «Загальних етичних принципів експериментів на тваринах», ухвалених Першим національним конгресом з біоетики (Київ, 2001).

Опік III ступеня наносили під тіопентал натрієвим наркозом мідними пластинами, нагрітими у кип’яченій воді до температури 97-1000, на епільовану поверхню шкіри спини тварини. Розміри ураження складали 18-20 \% поверхні тіла щурів. Піддослідних тварин декапітували на 21 добу, що відповідає стадії септикотоксемії опікової хвороби. Об'єктом дослідження був гіпокамп.

Забір матеріалу для електронномікроскопічних досліджень проводили відповідно до загальноприйнятої методики. Маленькі шматочки органу фіксували у розчині глютаральдегіду $(2,5 \%)$, приготовленого на основі фосфатного буферу із $\mathrm{pH}$ середовищем 7,2-7,4. Постфіксацію здійснювали у $1 \%$ розчині тетраокису осмію, після проводили його дегідратацію у пропіленоксиді та заливали в суміш епоксидних смол. Ультратонкі зрізи, виготовлені на ультрамікротомі LKB-3, контрастували ураніацетатом та цитратом свинцю відповідно до методу Рейнольдса і вивчали в електронному мікроскопі ПЕМ - 125 К [1].

\section{Результати досліджень та їх обговорення}

Проведені субмікроскопічні дослідження гіпокампа через 21 добу після нанесення експериментальної термічної травми встановили гетерогенні зміни нейроцитів, компонентів глії та мікроциркуляторного русла. У гіпохромних та різко гіперхромних нейронах гіпокампа відзначалися деструктивні змін різного ступеня, що проявлялося зміненим ядерноцитоплазматичним співвідношенням та значним пошкодженням ядра і органел нейроплазми. На мембранах розширених вакуолеподібних канальців ГЕС розташовані лише поодинокі рибосоми. Значно виражених змін зазнають й інші структури білоксинтезуючого апарату нейроцита - ядро, ядерце, комплекс Гольджі.

У «світлих» нейронах ядра мають електроннопрозору каріоплазму, ядерця в ній виявляються рідко, гетерохроматин розташований маргінально, каріолема не чітко контурована. Цитоплазма просвітлена, бідна на органели, частково гомогенна, у зв'язку із тотальним лізисом у ній трапляються поодинокі дезорганізовані видовженої форми зі світлим матриксом мітохондрії, наявні первинні і вторинні лізосоми (рис. 1). 


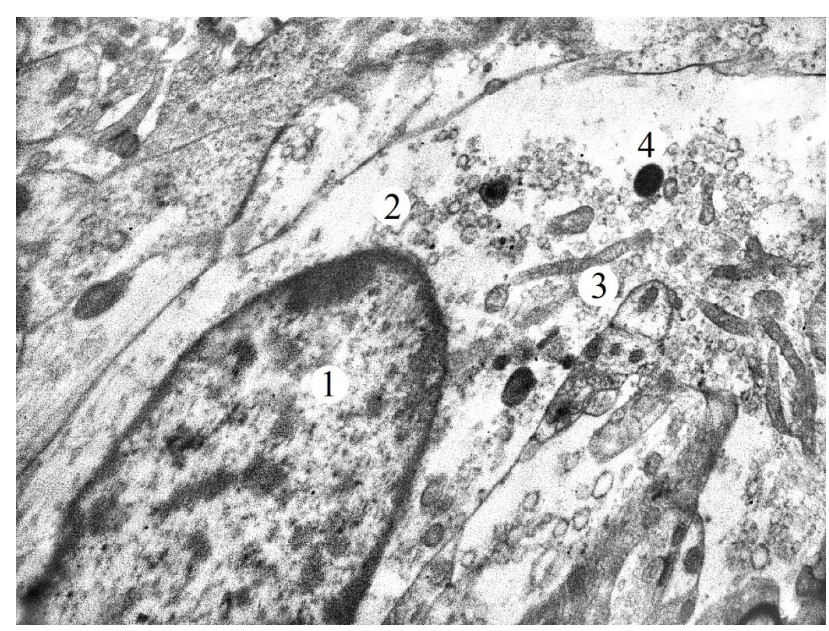

Рис. 1. Ультраструктурні зміни «світлого» нейроцита поля САЗ гіпокампа через 21 добу після експериментальної термічної травми. Ядро (1), просвітлена, деструктивно змінена цитоплазма (2), мітохондрії (3), лізосоми (4). Збільшенння: x 12000 .

Значні деструктивні зміни спостерігаються і в «темних» нейроцитах гіпокампа. У такому різновиді клітин наявна висока осміофілія нейроплазми і каріоплазми. Тіла таких нейроцитів зменшені, відростки тонкі, ядра пікнотично змінені. Нейроплазма насичена полісомами, канальця гранулярної ендоплазматичної сітки і цистерни комплексу Гольджі фрагментуються, округлої форми мітохондрії містять електроннопрозорий матрикс, майже позбавлені крист і нагадують великі вакуолі. Деякі мітохондрії знаходяться в стадії руйнування (рис. 2).

Значних змін зазнає астроцитарна глія гіпокампа. Деструктивні зміни проявляються появою великої кількості фагосом в цитоплазмі клітин як у тілах, так і у відростках. У електронно-прозорій каріоплазмі круглих та овальних ядер по периферії каріолеми розташований грудочками гетерохроматин (рис. 3). У цитоплазмі наявні мітохондрії із зміненою будовою, канальці гранулярної ендоплазматичної сітки нерівномірно потовщені. Наявний значний набряк цитоплазми астроцитарної ніжки. Астроцитарні гліоцити розташовуються групами, особливо біля гемокапілярів, які кровонаповнені (рис 4). Базальна мембрана чітко контурована, проте на деяких ділянках спостерігається ії̈ потовщення.

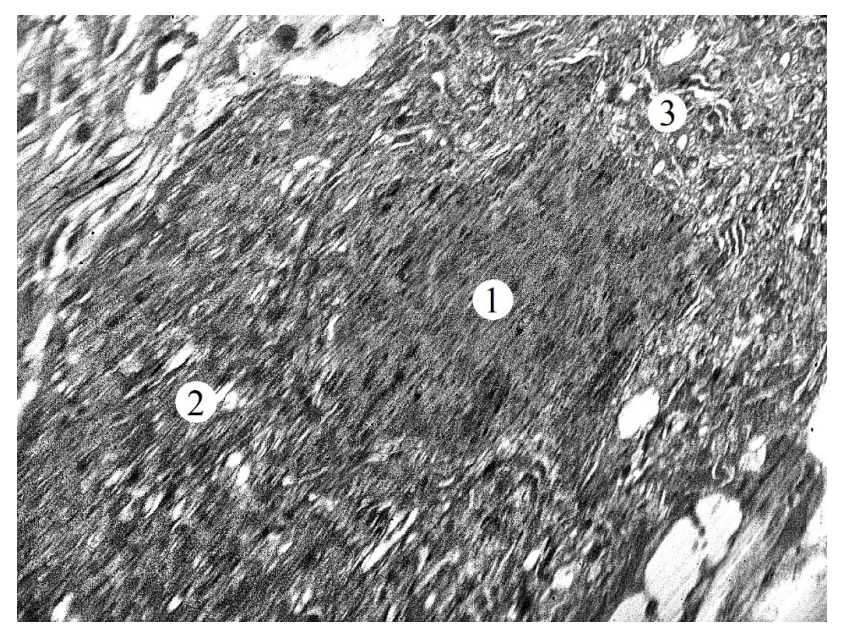

Рис. 2. Ультраструктурні зміни «темного» нейроцита поля САЗ гіпокампа через 21 добу після експериментальної термічної травми. Різко осміофільне, неправильної форми ядро (1) і електроннощільна нейроплазма (2), канальці гранулярної ендоплазматичної сітки (3). Збільшення: х 12000. 


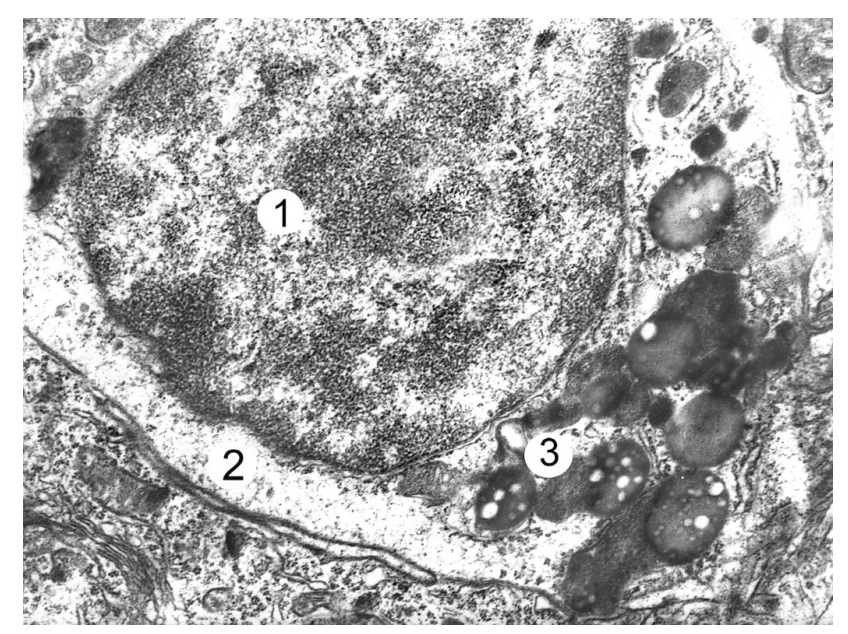

Рис. 3. Ультраструктура астроцита через 21 добу після експериментальної термічної травми. Ядро (1), змінені органели (2) у світлій аксоплазмі. Скупчення вторинних лізосом в цитоплазмі (3). Збільшення: х 15000.

Субмікроскопічно в цей термін досліду встановлено ремоделювання компонентів гемокапілярів. У зв'язку із суттєвим периваскулярним набряком та набряком цитоплазми ендотеліоцитів просвіти кровоносних капілярів звужені (рис. 5). Виявлено значні пікнотичні зміни, порушення форми та ущільнення ядер більшості ендотеліоцитів. Каріоплазма характеризується переважанням геторохроматину над еухроматином, що свідчить про зниження синтетичних процесів. Глибокі деструктивні зміни проявлялися у ендоплазматичній сітці, комплексі Гольджі та мітохондріях. Встановлено значне розширення канальців гранулярної ендоплазматичної сітки, неповну їх фрагментацію та часткове руйнування, на їх поверхні знаходяться поодинокі або повністю відсутні рибосоми. Деструктивно змінені мітохондрії стають округлими, їх матрикс просвітлений, спостерігається руйнування крист та порушення цілісності будови зовнішньої мембрани.

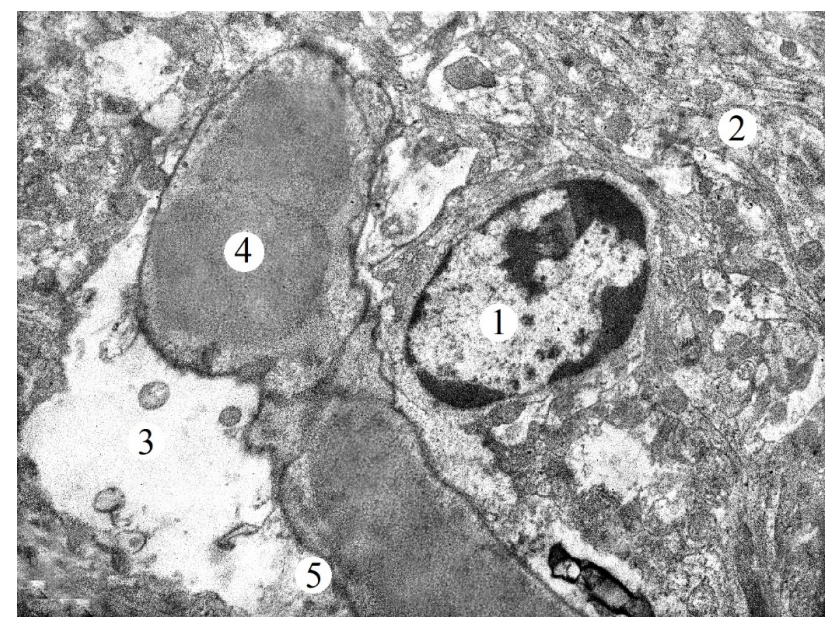

Рис. 4. Ультраструктурні зміни астроцита та гемокапіляра. Ядро астроцита (1), потовщені канальця гранулярної ендоплазматичної сітки (2), набряк цитоплазми (3), кровонаповнений просвіт капіляра (4), базальна мембрана (5). Збільшення: х 7000 . 


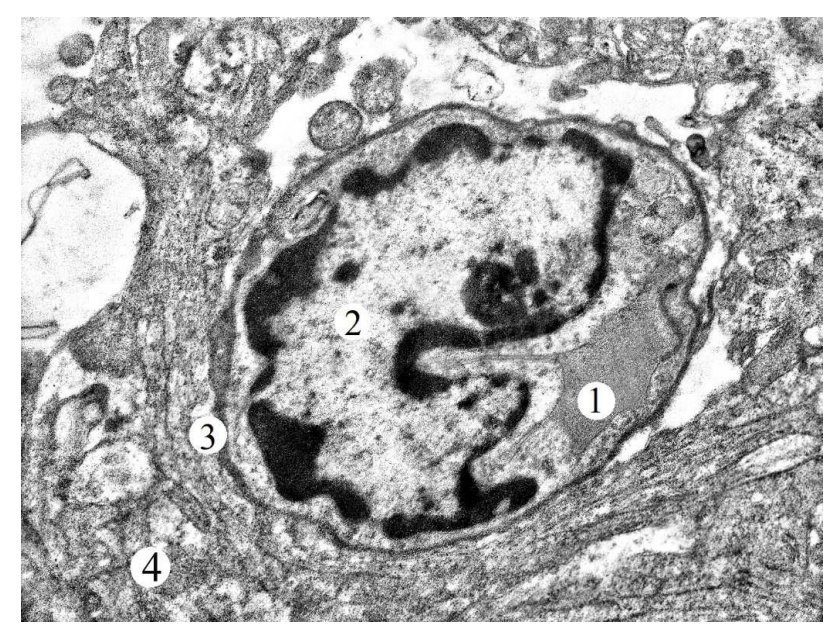

Рис. 5. Субмікроскопічний стан гемокапіляра гіпокампа на 21 добу після опікової травми. Вузький просвіт капіляра (1), змінене ядро ендотеліоцита (2), базальна мембрана (3), нейропіль (4). Збільшення: х 9000.

Трансендотеліальний транспорт сповільнений у зв'язку із незначною кількістю кавеол та піноцитозниз пухирців у складі набряклої цитоплазми ендотеліоцитів, а також відсутністю мікроворсинок на люменальній поверхні. Порушена електронна щільність базальної мембрани, на деяких ділянках вона стоншена або нерівномірно потовщена. Значно деструктивно змінені перицити, їх ядра пікнотичні, осміофільні, цитоплазма невелика за площею, але має електронносвітлі ділянки. Спостерігається значний периваскулярний набряк за рахунок потовщення відростків астроцитів.

\section{Висновки}

Проведені субмікроскопічні дослідження через 21 добу після експериментальної термічної травми, яка чинить патогенний вплив на гіпокамп уражених тварин, виявили значні зміни ультраструктурної перебудови органу. Встановлено, що головні та допоміжні (астроцити) нейрони гіпокампа зазнали глибоких деструктивно-дегенеративних змін. Зафіксовано значне ремоделювання та пошкодження структурної організації стінки гемокапілярів органу, розвиток периваскулярного набряку, недостатність трансендотеліального обміну, що призводить до значного порушення нейро-гліально-капілярних відносин гіпокампа.

1. Горальський Л. П, Хомич В. Т, Кононський О. І. Основи гістологічної техніки і морфофункціональні методи досліджень у нормі та при патології. Житомир : Полісся, 2011. 288 с.

2. Коваленко Т. М, Осадченко І. О, Чайка Н. В, Скибо Г. Г. Вплив гіпоксичного прекондиціювання на чутливість нейронів зони СА1 гіпокампа при експериментальній ішемії мозку. Український неврологічний журнал. 2019;1:75-82. doi: https://doi.org/10.30978/UNJ2019-1-75.

3. Нетюхайло Л. Г, Харченко С. В, Костенко А. Г. Патогенез опікової хвороби (частина 1). Світ медицини та біології. 2011;1:127-31.

4. Нетюхайло Л. Г, Харченко С. В, Костенко А. Г. Патогенез опікової хвороби (частина 2). Світ медицини та біології. 2011;1:131-35.

5. Півнева Т. А, Скибо Г. Г, Коваленко Т. М, Осадченко І. А, Цупиков О. М. Структурні зміни в гіпокампі при експериментальній ішемії мозку. Украӥнський неврологічний журнал. 2006;1:86-91.

6. Черкасов В. Г, Василенко Д. А, Парахін А. А. Ультраструктурні зміни нейронів фронтальної кори щура під впливом інтоксикації метилтретбутиловим ефіром. Нейрофізіологія. 2010;42(6):471-481.

7. Greenhalgh D. G. Management of Burns. New England Journal of Medicine. 2019;380(24):2349-2359. doi:10.1056/nejmra1807442

8. Hicks K. E, Huynh MNQ, Jeschke M, Malic C. Dermal regenerative matrix use in burn patients: A systematic review. Journal of Plastic, Reconstructive \& Aesthetic Surgery. 2019;72(11):1741-1751. doi:10.1016/j.bjps.2019.07.021

9. Nebesna Z. M, Volkov K. S, Bodnar P. Ya, Shuturma O. Ya, Kramar S. B. Submicroscopic changes of the respiratory alveolar macrophages at the late period after experimental thermal injury and in combined use of 
lyophilized xenograft substrate and surfactant. World of Medicine and Biology. 2018; 2(64):165-169. doi:10.26724/2079-8334-2018-2-64-165-169.

10. Zhang Q. H, Li J. C, Dong N, Tang L. M, Zhu X. M, Sheng Z. Y et al. Burn injury induces gelsolin expression and cleavage in the brain of mice, Neuroscience. 2013;3:60-72.

\section{References}

1. Horalskyi L. P, Khomych V. T, Kononskyi O. I. Osnovy histolohichnoi tekhniky i morfofunktsionalni metody doslidzhen u normi ta pry patolohii. Zhytomyr : Polissia. 2011. 288 s. [in Ukrainian]

2. Kovalenko T. M, Osadchenko I. O, Chaika N. V, Skybo H. H. Vplyv hipoksychnoho prekondytsiiuvannia na chutlyvist neironiv zony SA1 hipokampa pry eksperymentalnii ishemii mozku. Ukrainskyi nevrolohichnyi zhurnal. 2019;1:75-82. doi: 10.30978/UNJ2019-1-75 [in Ukrainian]

3. Netiukhailo L. H, Kharchenko S. V, Kostenko A. H. Patohenez opikovoi khvoroby (chastyna 1). Svit medytsyny ta biolohii. 2011;1:127-31. [in Ukrainian]

4. Netiukhailo L. H, Kharchenko S. V, Kostenko A. H. Patohenez opikovoi khvoroby (chastyna 2). Svit medytsyny ta biolohii. 2011;1:131-35. [in Ukrainian]

5. Pivneva T. A, Skybo H. H, Kovalenko T. M, Osadchenko I. A, Tsupykov O. M. Strukturni zminy v hipokampi pry eksperymentalnii ishemii mozku. Ukrainskyi nevrolohichnyi zhurnal. 2006;1:86-91. [in Ukrainian]

6. Cherkasov V. H, Vasylenko D. A, Parakhin A. A. Ultrastrukturni zminy neironiv frontalnoi kory shchura pid vplyvom intoksykatsii metyltretbutylovym efirom. Neirofiziolohiia. 2010;42(6):471-481. [in Ukrainian]

7. Greenhalgh D. G. Management of Burns. New England Journal of Medicine, 2019; 380(24):2349-2359. doi:10.1056/nejmra1807442

8. Hicks K. E, Huynh MNQ, Jeschke M, Malic C. Dermal regenerative matrix use in burn patients: A systematic review. Journal of Plastic, Reconstructive \& Aesthetic Surgery. 2019;72(11):1741-1751. doi:10.1016/j.bjps.2019.07.021

9. Nebesna Z M, Volkov K S, Bodnar P. Ya, Shuturma O. Ya, Kramar S. B. Submicroscopic changes of the respiratory alveolar macrophages at the late period after experimental thermal injury and in combined use of lyophilized xenograft substrate and surfactant. World of Medicine and Biology. 2018; 2(64):165-169. doi:10.26724/2079-8334-2018-2-64-165-169.

10. Zhang Q. H, Li J. C, Dong N, Tang L. M, Zhu X. M, Sheng Z. Y et al. Burn injury induces gelsolin expression and cleavage in the brain of mice, Neuroscience. 2013;3:60-72.

\section{S. O Lytvynyuk, P. H Lykhatskyi, I. B Pryvrotska, N. Y Lisnychuk}

I. Gorbachevsky Ternopil National Medical University, Ukraine

\section{ULTRASTRUCTURAL FEATURES OF NEURO-GLIAL-CAPILLARY RELATIONSHIPS OF THE HIPPOCAMPAL CA3 AREA ON THE 21st DAY AFTER EXPERIMENTAL THERMAL INJURY}

Severe thermal injury leads to a number of morphofunctional changes that occur in violation of integrity or loss of skin in deep burns and endogenous intoxication on the background of which significant structural and metabolic disorders in all organs and systems of the affected organism are developed. This is manifested in a complicated symptom complex of burn disease. Changes in the central nervous system play an important role in the pathogenesis of burn injury, the nature and depth of morphofunctional changes in individual cerebral structures, in particular in the hippocampus (central organ of the limbic system, which is especially sensitive to various pathogens), after thermal lesions remain poorly studied.

The aim of our study was to establish the features of submicroscopic changes in the structural components of the hippocampus after 21 days under conditions of experimental thermal injury.

The experimental study was performed on white laboratory male rats. Third-degree burns were applied under thiopental-sodium anesthesia with copper plates heated in boiled water to a temperature of $97-100^{\circ} \mathrm{C}$. The size of the affected area was $18-20 \%$ of the rats' body epilated surface. Histological changes were studied on the 21 st day from the beginning of the experiment. For electron microscopy, the obtained ultrathin sections were contrasted with uranyl acetate and lead citrate according to the Reynolds method.

It was found that on the 21st day after the experimental thermal injury significant alternative changes in neurons, glial cells and the microcirculatory tract of the hippocampus were defined which 
developed on the background of excessive endogenous intoxication. Neurons are hypochromic and sharply hyperchromic, disorganized and have an altered shape; there are cell-free areas. Endoplasmic reticulum, Golgi complex, mitochondria are destructively changed. Degeneration of macroglial cells has been noticed. Their nuclei are high in electron density in which heterochromatin predominates. Destruction and lysis of organelles, lysosomes have also been found in the cytoplasm. These changes of astrocytic glia lead to impaired trophic function and the relation between astrocytes and blood capillaries. Hemocapillaries wall remodeling is manifested by the total edema, compaction of the basement membrane. The lumenal surface of the plasmolemma of endothelial cells is homogeneous, indistinctly contoured. The cytoplasm of endothelial cells is swollen, enlightened, and poor in organelles; there is a small number of micropinocytic bubbles and vesicles.

Keywords: hippocampus, CA3 area, neurons, hemocapillaries, submicroscopic changes, thermal injury.

Надійшла 19.05.2021. 